\title{
Migracijske i etničke teme - bibliometrijska analiza časopisa za razdoblje od 1985. do 2013.
}

\author{
DOI: $10.11567 /$ met.30.3.8 \\ UDK: 050:[314:323.1]:001.811"1985/2013" \\ Izvorni znanstveni rad \\ Primljeno: 2.10.2014. \\ Prihvaćeno: 26.1.2015.
}

\section{Davor Jokić}

Tekstilno-tehnološki fakultet, Sveučilište u Zagrebu, Zagreb

davor.jokic@ttf.hr

\section{Delfa Bartulović-Barnjak}

Zagreb

delpha07@gmail.com

\section{SAŽETAK}

U radu se analizira časopis Migracijske $i$ etničke teme tijekom tri desetljeća njegova izlaženja. Uzorak za istraživanje činili su svi brojevi časopisa od 1985. do 2013. s ukupno 497 radova, na kojima je provedena bibliometrijska analiza. Analizirani radovi svrstani su u kategorije izvorni znanstveni rad, prethodno priopćenje, pregledni rad te konferencijski i stručni rad. Sastavnice bibliografskih opisa pogodne za provedbu bibliometrijske analize koje smo uzeli u obzir bile su vrsta rada, godina, godište/ broj, autor, broj autora, institucija, broj stranica rada i jezik rada. Posebna pozornost $\mathrm{u}$ istraživanju usmjerena je na analizu citiranih referenci u radovima. Tom citatnom analizom utvrđeni su podaci o vrsti citiranih publikacija, količini citirane publikacije, autoru, godini objave citirane publikacije, nazivu časopisa ako je posrijedi bio članak te o tome je li riječ o domaćoj ili stranoj publikaciji. Analiza je provedena na temelju uzimanja uzoraka iz tri vrste citiranih publikacija: knjiga, zbornika i časopisa. Da bi se dobio uvid u recepciju rezultata istraživanja objavljenih u časopisu Migracijske $i$ etničke teme, provedena je analiza posredne citiranosti preko časopisa indeksiranih u bazama Web of Science i Scopus. Rezultati dobiveni ovim istraživanjem mogli bi poslužiti kao smjernice razvoja časopisa.

KLJUČNE RIJEČI: Migracijske i etničke teme, bibliometrijska analiza, citatna analiza, znanstveni časopis, Hrvatska

\section{UVOD}

Znanstveni časopis, ne samo u prirodnim, biomedicinskim i tehničkim znanostima nego sve više i u društvenim, pa i humanističkim, osnova je znanstvene komunikacije. U prilog toj tvrdnji ide činjenica da primjerice 
u Hrvatskoj, prema podacima dostupnim na portalu znanstvenih časopisa Republike Hrvatske (http://hrcak.srce.hr/), časopisi iz područja društvenih i humanističkih znanosti imaju udio od šezdesetak posto. Uloga časopisa u znanstvenoj komunikaciji odvija se kroz produkciju, konzumaciju i diseminaciju znanstvenih i stručnih informacija relevantnoj znanstvenoj javnosti. Moglo bi se reći kako časopis ima ključnu ulogu u razvoju znanosti, odnosno određene znanstvene discipline, jer je svakome znanstveniku važno objaviti rezultate svog istraživanja, koji će posljedično u manjoj ili većoj mjeri utjecati na razvoj područja znanosti kojim se bavi, a možda i šire.

Pokretanje određenog časopisa zapravo govori o postojanju kritične mase znanstvenika i stručnjaka koji imaju potrebu artikulirati određenu znanstvenu i stručnu problematiku te je podijeliti s relevantnom akademskom zajednicom. Postojanje i opstojanje časopisa Migracijske i etničke teme (MET) u kontekstu Hrvatske kao male zemlje koja je izvan govornog područja velikih jezičnih skupina jasan je pokazatelj važnosti problematike kojom se bavi, odnosno zrelosti znanstvene sredine (Jokić i Zauder, 2013).

Bibliometrijska istraživanja časopisa u području društvenih i humanističkih znanosti u usporedbi s takvim analizama za prirodne, biomedicinske i tehničke znanosti donedavno su bila relativno rijetka i u svijetu i u Hrvatskoj. Mogući je razlog i važnost uloge knjiga kao komunikacijskog medija u većini polja i disciplina društvenih, a pogotovo humanističkih znanosti. Kao dokaz da je postojao i postoji interes za istraživanje časopisa iz različitih polja društvenih znanosti, navest ćemo samo neka od istraživanja: Dukić, 1990; Puljiz i Štambuk, 1992; Petak, Puljiz i Štambuk, 2002; Vojnić, 2005; Švenda Radeljak, 2006; Jokić i Zauder, 2013; Pricopie, 2013; Nambiar, 2013; Bullis i Irving, 2013. U nekim dinamičnijim poljima društvenih znanosti časopis ima dominantniju ulogu, pa se više i istražuje, na primjer u ekonomiji i psihologiji (Azar, 2014; Haley, 2014).

Časopis Migracijske $i$ etničke teme po svojoj je definiciji interdisciplinaran i može se očekivati da ima obilježja i društvenih i humanističkih časopisa. Iako je uloga časopisa u znanosti u osnovi ista neovisno o području, oni se razlikuju po svojim oblikovnim karakteristikama te načinima objavljivanja rezultata istraživanja i znanstvenih spoznaja, npr. vrstama članaka, strukturi članaka, vrstama i oblicima navođenja upotrijebljene literature i sl.

Časopis Migracijske i etničke teme pokrenut je 1985. i vezan je uz osnutak Centra za istraživanje migracija i narodnosti u Zagrebu. Isprva je nosio naziv Migracijske teme: časopis za istraživanje migracija i narodnosti. Izdavač je časopisa Institut za migracije i narodnosti. Teme kojima se bavi jesu aspekti migracija, etničnosti i identiteta s gledišta različitih društvenih i humani- 
stičkih disciplina poput sociologije, antropologije, povijesti, demografije, društvene geografije, psihologije, politologije, ekonomije, prava, lingvistike i dr. Njegov prvi urednik i osnivač bio je Milan Mesić. Dinamika njegova izlaženja u to vrijeme bila je četiri puta godišnje, što može biti pokazatelj važnosti i zanimljivosti problematike istraživanja, ali i postojanja kritične mase istraživača i stručnjaka. Časopis 2001. mijenja naslov u Migracijske $i$ etničke teme. Njegovi su se urednici od 2001. do danas dinamičnije izmjenjivali: Emil Heršak, Laura Šakaja, Jadranka Čačić-Kumpes, Sanja Lazanin te Sanja Klempić Bogadi, urednica od 2013.

Svrha i cilj ovog istraživanja jesu da na osnovi dostupnih bibliometrijskih pokazatelja dobijemo uvid u razvoj ovoga hrvatskog interdisciplinarnog časopisa tijekom 29 godina izlaženja i njegovu važnost u kontekstu sredine $u$ kojoj se razvijao i pridonosio da se opisana problematika približi zainteresiranima. Uz razvoj časopisa posebna pozornost bit će usmjerena na razdoblje od 2002. do 2013. kao recentno razdoblje, u kojem će biti vidljive promjene nastale kao rezultat djelovanja četiriju uredništava. Za prepoznatljivost i vidljivost časopisa od vitalne je važnosti zastupljenost u relevantnim, ali i prestižnim svjetskim citatnim i bibliografskim bazama podataka. Iako časopis Migracijske i etničke teme nije indeksiran u bazama Scopus i Web of Science, pa nije moguće dobiti njegovu izravnu citiranost i podatke o faktoru odjeka (Impact Factor, IF) ili SJR (SCImago Journal Ranking) časopisa, zahvaljujući mogućnostima koje pružaju te dvije baze posredno smo došli do podataka o citiranosti radova iz časopisa, koje su citirali hrvatski i strani časopisi indeksirani u tim bazama. Važno je napomenuti da je časopis pod nazivom Migracijske teme bio selektivno uključen u bazu podataka Medline (jedanaest radova), koja je primarno biomedicinska baza. Petnaest radova iz časopisa, od 1985. do 1998., uključeno je u bazu Scopus, no to ne znači da je u njoj kontinuirano indeksiran. Relevantne bibliografske baze kao izvori znanstvene literature za problematiku kojom se bavi časopis jesu Sociological Abstract i SocINDEX. Časopis Migracijske i etničke teme indeksiran je u obje te baze kao i u Worldwide Political Science Abstracts, Linguistics and Language Behavior Abstracts, International Bibliography of the Social Sciences i CEEOL - Central and Eastern European Online Library.

\section{METODOLOGIJA I UZORAK}

Uzorak za ovo istraživanje činili su svi brojevi časopisa Migracijske teme: časopis za istraživanje migracija i narodnosti i Migracijske $i$ etničke teme. Svi radovi (ukupno 511 rada) pregledani su de visu, od 1985. do 2013. Biblio- 
metrijska analiza provedena je na 497 radova. Na četrnaest radova, iako je bila riječ o kategoriziranim člancima, izvornim znanstvenim radovima, prethodnim priopćenjima, te preglednim i stručnim radovima, nismo mogli provesti bibliometrijsku analizu jer su objavljeni na ćirilici. Zbog nepoznavanja tog pisma te relativno malog broja radova objavljenom na njemu ( $2,7 \%$ od ukupnog broja objavljenih radova) odlučili smo samo istaknuti tu činjenicu kao posebnost.

Kako bi se lakše mogli pratiti trendovi razvoja časopisa kroz vrste radova, kategorizirali smo ih na izvorni znanstveni rad, prethodno priopćenje, pregledni rad, stručni rad te konferencijski rad. Kategorizaciju smo preuzeli onako kako je odredilo uredništvo časopisa u trenutku objavljivanja radova. Koliko je osjetljivo pitanje kategorizacije radova, može se ilustrirati na primjeru bibliometrijske analize časopisa Sociologija sela, gdje su prvi empirijski radovi, koji su uvodili istraživačku i analitičku komponentu, bili klasificirani kao stručni ili čak kao prilozi ili osvrti. Dapače, u rubrici »Osvrti $\ll \mathrm{u}$ to su vrijeme objavljivani članci sa svim odlikama znanstvenog rada uključujući popis citirane i upotrijebljene literature (Jokić i Zauder, 2013). To upućuje na važnost uloge uredništva i politike objavljivanja radova u časopisu kao i oblika znanstvene komunikacije u određenoj znanstvenoj disciplini.

Kategorizacijom radova željeli smo dobiti uvid u moguće trendove razvoja znanstvene komunikacije. Izvorni znanstveni rad treba sadržavati značajan doprinos znanstvenoj problematici ili njezinu shvaćanju, pregledni rad izvješćuje o specifičnom problemu kroz prikupljanje i analizu informacija u publiciranim radovima koji su pridonijeli objašnjenju tog područja, a prethodno priopćenje može sadržavati jednu ili više znanstvenih informacija, ali bez pojedinosti na temelju kojih bi bilo moguće provjeriti iznesene podatke, dok se, s druge strane, stručni rad služi postojećim znanjem te ga primjenjuje na predmet svoga istraživanja (Matešić, 1984: 192). Preciznije, stručni rad karakterizira upotreba poznate metodologije na srodnom uzorku i najčešće ne sadržava nove znanstvene spoznaje. Cjeloviti i kritički prikaz područja ili problema istraživanja o kojemu je već objavljena znanstvena spoznaja donosi pregledni rad.

Analizom podataka jasno smo utvrdili i opisali formalna (uređivačkoizdavačka) obilježja, rast, produktivnost, znanstvenu suradnju te sadržajna i tematska obilježja upotrijebljene literature iz određenoga predmetnog područja. U obzir smo uzeli sljedeće sastavnice bibliografskih opisa pogodne za bibliometrijsku analizu: vrstu rada, godinu, godište/broj, autora, broj autora, instituciju, broj stranica rada i jezik rada. U svrhu analize citiranih 
referenci izrađena je priručna baza podataka koja je sadržavala podatke o vrsti citiranih publikacija, broju citiranih publikacija, autoru, godini odnosno starosti objave citiranih publikacija, nazivu časopisa ako je posrijedi bio članak te o tome je li riječ o domaćoj ili stranoj publikaciji. Analiza je provedena na temelju uzimanja uzoraka iz tri vrste citiranih publikacija: knjiga, radova u časopisima i zbornika radova. Kako uredništvo časopisa navodi da se radovi uglavnom objavljuju na četiri jezika, hrvatskome, engleskom, francuskom i ruskom, provedena je i jezična analiza objavljenih radova. Radi provjere recentnosti upotrijebljene literature provedena je analiza prosječne starosti citiranih publikacija te određen medijan starosti citiranih publikacija kako bi se dobila centralna vrijednost.

Na razdoblje od 2002. do 2013. stavljen je poseban naglasak u ovom istraživanju. Iako je časopis promijenio ime 2001., za početak posebnog razdoblja istraživanja uzeli smo 2002., kada se nakon jedanaestogodišnjega uredničkog mandata mijenja uredništvo. Na našu odluku utjecala je i činjenica da je upravo na prijelazu iz 2001. u 2002. s promjenom uredništva zabilježen najveći pad prosječnog broja stranica radova, s 21,7 na 14,5 (slika 1). U cjelokupnom razdoblju izlaženja časopisa nije zabilježen takav pad te bi on mogao biti pokazatelj promjene uredništva i uredničke politike, što bi zahtijevalo posebnu analizu. Nadalje, naglasak je stavljen na ulogu uredništva jer je izravno odgovorno za dinamiku izlaženja i sadržaj časopisa (Jokić, 2001).

Ovim istraživanjem obuhvaćena je i analiza citiranosti radova iz časopisa pod oba naslova, i to u citatnim bazama Scopus i Web of Science. Časopis zasad nije indeksiran ni u jednoj od te dvije baze. Posrednom citiranošću, tj. analizom referenci radova objavljenih u časopisima koje indeksiraju te dvije baze, došli smo do podataka koji su časopisi i s kojom učestalošću citirali radove iz časopisa. Konkretno, do podataka iz baze Scopus došli smo upotrebom opcije Document search/references, a iz baza WoS Cited reference search. U oba slučaja upotrijebljeni su pojmovi Migracijske teme i Migracijske i etnicke teme, bez dijakritičkih znakova.

\section{REZULTATI I DISKUSIJA}

\subsection{Vrsta objavljenih radova i jezik objavljivanja}

Vrste radova koje smo uzeli kao uzorak za analizu časopisa bili su izvorni znanstveni radovi, prethodna priopćenja, pregledni radovi, stručni radovi i konferencijski radovi. Od ukupnog broja svih radova (497) urednici i uredništva časopisa označili su 58,0\% radova (288) kao izvorne znanstvene 
radove. Prethodna priopćenja bila su zastupljena s udjelom od 17,5\% (87 radova), pregledni radovi s udjelom od 20,1\% (100 radova), dok je stručnih radova bilo četrnaest $(2,8 \%)$, a konferencijskih radova osam.

Analiziramo li opsežnost radova mjerenu brojem stranica, dobivamo podatak da je njihova prosječna duljina bila 15,6 stranica. U 1995. i 2013. bilježi se maksimalna vrijednost od 23,3 stranice u prosjeku godišnje, a 1987. minimalna vrijednost od jedanaest stranica. Relativna ujednačenost broja stranica uz postupno povećanje opsežnosti izraženija je u prvom desetljeću izlaženja časopisa (slika 1). Najizraženiji pad u prosječnom broju stranica zabilježen je na prijelazu iz 2001. u 2002., što je ujedno i razdoblje promjene uredništva, a moguće i uredničke politike. Od 2002. do 2013. bilježi se pozitivan trend $u$ prosječnom broju stranica po objavljenom radu te časopis 2013. dolazi na razinu iz 1995., kada je zabilježen isti broj stranica, odnosno prosječno 23,3 po objavljenom radu.

Slika 1. Prosječni broj stranica objavljenih radova po godini izlaženja časopisa

Figure 1. Average number of pages of published papers by year of journal publication

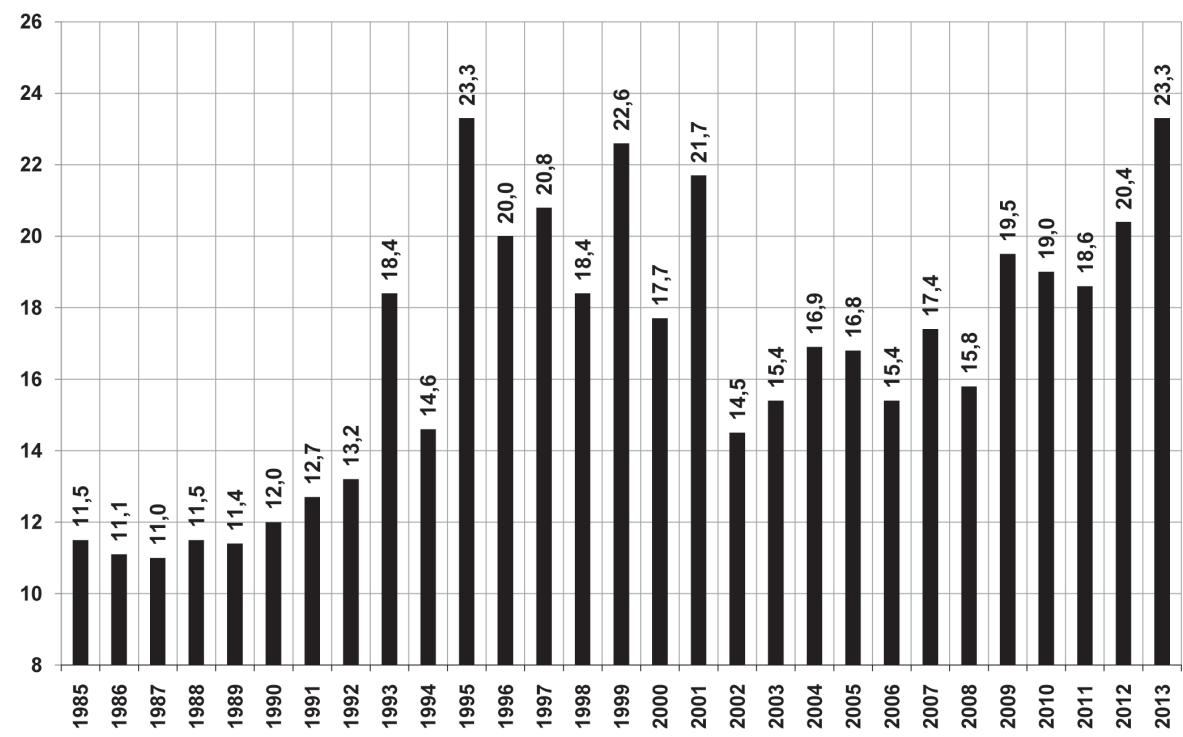

Promjene u duljini članaka pokazatelji su promjena komunikacijskog obrasca i relativno se često upotrebljavaju u bibliometrijskim istraživanjima 
(Jokić, Zauder i Letina, 2012). Za usporedbu, prema važećem Pravilniku o izborima $u$ znanstvena znanja ${ }^{1} \mathrm{u}$ području humanističkih znanosti, jedan od osnovnih uvjeta jest opseg objavljenog rada.

Što se tiče broja radova na godišnjoj razini, osim u prvih deset godina izlaženja, bilježimo ujednačenost, dok je u posljednjem razdoblju od 2002. do 2013. prosječno šesnaest radova godišnje. Maksimalni broj bio je 1990., 42 rada, a minimalni 1994., osam radova. Broj radova objavljenih u časopisu može biti pokazatelj stanja u znanstvenoj disciplini te govoriti o masi znanstvenika i istraživanja u određenom području. Podatak da je časopis 1990. objavio 42 rada može se opravdati činjenicom da je bio orijentiran na prostor cijele bivše Jugoslavije. S druge strane, samo osam radova objavljenih 1994. može biti odraz ratnog stanja u Hrvatskoj (slika 2).

Slika 2. Broj objavljenih radova po godini od 1985. do 2013.*

Figure 2. Number of published papers by year, 1985-2013

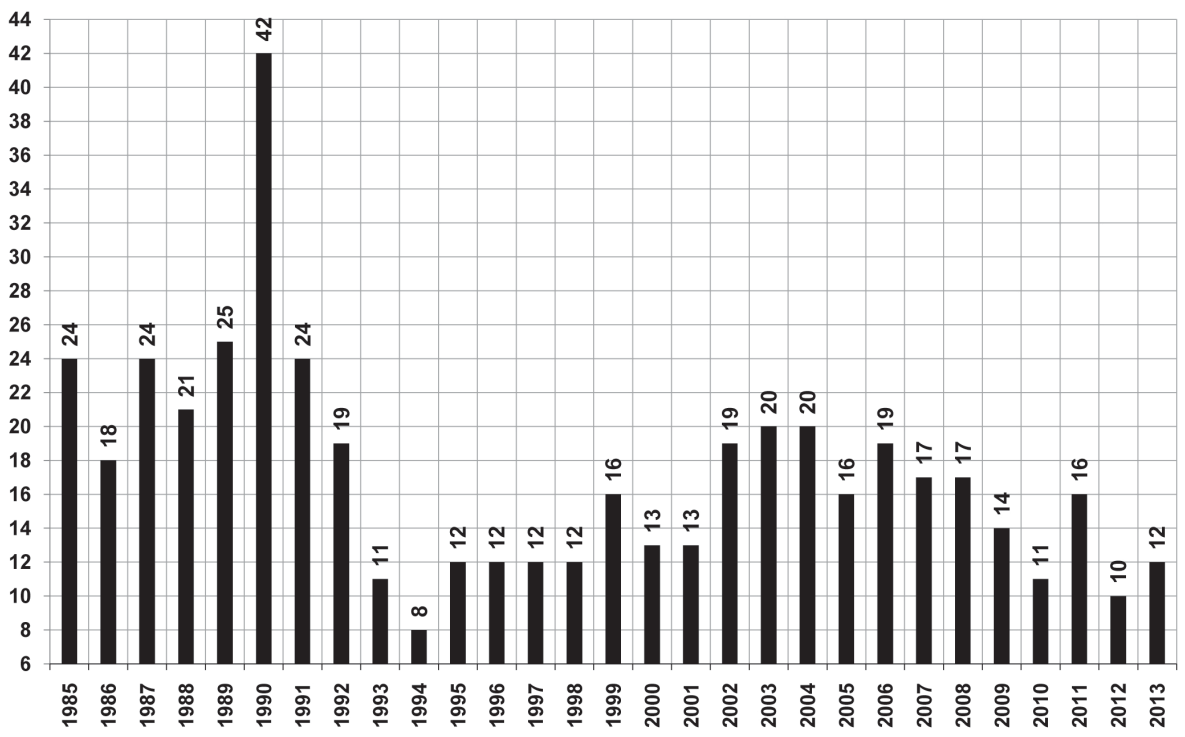

\footnotetext{
* Napomena: budući da su u analize uključeni radovi pisani isključivo na latinici dolazi do razilaženja u stvarnom broju objavljenih radova po godini. Smatra se važnim ukazati na razlike u ukupnom broj objavljenih radova: 1986. objavljeno je ukupno 19 radova, 1987. - 25 radova, 1989. - 26 radova, 1994. - 9 radova, 1997. - 13 radova, 1998. - 15 radova, 2002. - 22 rada, 2005. -18 radova i 2006. - 20 radova.
}

1 http://narodne-novine.nn.hr/clanci/sluzbeni/289156.html (07. 12. 2014.). 
Jezik na kojem su znanstveni i stručni radovi pisani vrlo je važan faktor koji upućuje na otvorenost časopisa za suradnju, ne samo u svome užem okruženju nego i u međunarodnoj zajednici. Časopis Migracije i etničke teme u svom gotovo tridesetogodišnjem postojanju objavljivao je radove na hrvatskome, engleskom, ruskom, slovenskom, francuskom, srpskom, makedonskom i španjolskom. U brojkama to izgleda ovako: očekivano najzastupljeniji bili su radovi na hrvatskom jeziku, njih 351 ili 68,7\%; slijede ih radovi na engleskome njih 114 ili 22,3\%, na ruskome i na slovenskome po trinaest ili 2,5\%, osam na francuskome, deset na srpskome te po jedan na španjolskom i makedonskom jeziku (slika 3).

Slika 3. Zastupljenost jezika u objavljenim radovima tijekom cjelokupnoga razdoblja izlaženja časopisa

Figure 3. Representation of languages in published papers during the entire period of journal publication

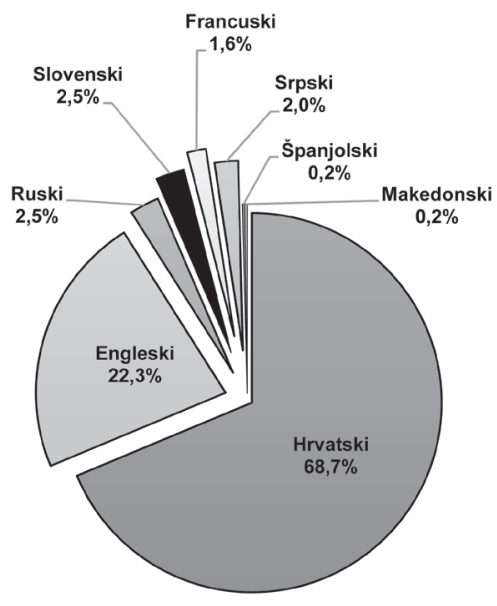

Iako časopis Migracijske $i$ etničke teme ima međunarodni karakter kako tematikom članaka tako i međunarodnim sastavom autora, recenzenata, uredništva i izdavačkoga savjeta, sa $68,7 \%$ radova na hrvatskom jeziku te prema definiciji indeksa ERIH Plus ${ }^{2}$ časopis ima nacionalni karakter. No kako je čitljiv svima u regiji te ima $2,5 \%$ objavljenih radova na slovenskom te ukupno 2,2\% objavljenih radova na srpskom i na makedonskom jeziku možemo reći kako je MET i regionalni časopis.

2 https://dbh.nsd.uib.no/publiseringskanaler/erihplus/about/index (07. 12. 2014.). 
Radovi na ruskom jeziku i na ćirilici za današnje prilike, a napose u Hrvatskoj, nemaju jednaki status kao oni pisani na latinici. Ponajprije se misli na mlađe generacije znanstvenika koje nisu imali prilike kroz obrazovni sustav naučiti ćirilicu. Iako se u vrijeme objavljivanja tih radova cijela jugoslavenska znanstvena zajednica koristila ćirilicom, danas to nije slučaj i stoga vrijedni rezultati radova objavljenih na ćirilici teško dolaze do šire publike, odnosno one koja se služi latinicom.

Ako časopis želi biti međunarodno vidljiviji, što, između ostaloga, znači $i$ indeksiranost u prestižnim svjetskim bazama Web of Science i Scopus, trebao bi objavljivati rezultate istraživanja zanimljive široj znanstvenoj zajednici te pisati na stranim jezicima, a poglavito na engleskom jeziku. Naime općeprihvaćena je činjenica da je engleski uobičajeni jezik svjetske znanosti. U prilog pokušajima za stjecanjem međunarodnoga statusa govori i podatak da je 22,3\% radova objavljeno na engleskom jeziku. Osim toga napori svih uredništava da povećaju međunarodnu prepoznatljivost MET-a vidljivi su kroz široki raspon zastupljenih disciplina kao što su sociologija, antropologija, povijest, demografija, društvena geografija, psihologija, politologija, ekonomija, pravo i lingvistika s naglaskom na migracije, etničnosti i identitet.

Na temelju navedenih podataka, sustavne formalne kategorizacije radova, visokog udjela znanstvenih radova, što uključuje i pregledne radove i prethodna priopćenja, relativne konzistentnosti duljine članaka i relativno dobre zastupljenosti radova na engleskom jeziku može se zaključiti da časopis Migracijske i etničke teme prema formalno-oblikovnim karakteristikama ima odlike znanstvenog časopisa.

\subsection{Analiza autorâ i ustanova}

U 29 godina izlaženja MET-a promijenilo se šest glavnih urednika. Funkciju prvoga glavnog urednika od 1985. do 1989. obavlja Milan Mesić koji je ujedno i autor šesnaest objavljenih radova ukupno u časopisu. Od 1990. do 2001. na toj je funkciji bio Emil Heršak, autor ukupno devetnaest radova, zatim Laura Šakaja od 2002. do 2004., autorica dvaju radova, pa od 2005. do 2008. Jadranka Čačić-Kumpes s objavljenih dvanaest radova. Pretposljednja je glavna urednica Sanja Lazanin od 2009. do 2012., autorica četiriju objavljenih radova. Produktivnost ostalih autora po uredničkim razdobljima vidljiva je iz tablice 1. 
Tablica 1. Pet najproduktivnijih autora u časopisu Migracijske i etničke teme po uredničkim razdobljima, 1985. - 2012.

Table 1. Five most productive authors in the journal Migration and Ethnic Themes by editorial periods, 1985-2012

\begin{tabular}{|c|c|c|c|c|}
\hline $\begin{array}{l}\text { Milan Mesić } \\
(1985 .-1989 .)\end{array}$ & $\begin{array}{c}\text { Emil Heršak } \\
\text { (1990. - 2001.) }\end{array}$ & $\begin{array}{l}\text { Laura Šakaja } \\
(2002 .-2004 .)\end{array}$ & $\begin{array}{c}\text { Jadranka Čačić- } \\
\text { Kumpes } \\
(2005 . \text { - 2008.) }\end{array}$ & $\begin{array}{l}\text { Sanja Lazanin } \\
(2009 .-2012 .)\end{array}$ \\
\hline Heršak, E. (6) & Heršak, E. (11) & Babić, D. (6) & David, M. K. (3) & Lajić, I. (3) \\
\hline Švob, M. (5) & $\begin{array}{c}\text { Čičak-Chand, } \\
\text { R. (9) }\end{array}$ & Lajić, I. (3) & Babić, D. (2) & $\begin{array}{l}\text { Gregurović, } \\
\text { S. (2) }\end{array}$ \\
\hline Anić, J. (4) & Mesić, M. (8) & Raduški, N. (3) & $\begin{array}{c}\text { Berthomière, } \\
\text { W. (2) }\end{array}$ & $\begin{array}{c}\text { Klempić Bogadi, } \\
\text { S. (2) }\end{array}$ \\
\hline Čičak, R. (4) & $\begin{array}{c}\text { Čačić-Kumpes, } \\
\text { J. (8) }\end{array}$ & Klempić, S. (2) & Banovac, B. (2) & Kuti, S. (2) \\
\hline $\begin{array}{c}\text { Pavlinić-Wolf, } \\
\text { A. (4) } \\
\text { Perunović, S. (4) }\end{array}$ & $\begin{array}{l}\text { Lajić, I. (8) } \\
\text { Podgorelec, } \\
\text { S. (8) }\end{array}$ & $\begin{array}{l}\text { Mesić, M. (2) } \\
\text { Molodikova, } \\
\text { I. (2) }\end{array}$ & $\begin{array}{l}\text { Boneta, Ž. (2) } \\
\text { Lajić, I. (2) } \\
\text { Gregurović, } \\
\text { S. (2) } \\
\text { Čičak-Chand, } \\
\text { R. (2) }\end{array}$ & Mesić, M. (2) \\
\hline
\end{tabular}

Zanimljiv je podatak kako je $\mathrm{u}$ pet najproduktivnijih autora $\mathrm{u}$ dvadesetdevetogodišnjem razdoblju troje urednika: Emil Heršak, Milan Mesić te Jadranka Čačić-Kumpes (slika 4). Taj je podatak indikativan, i to s više aspekata. Iako urednici znanstvenih časopisa, po definiciji znanstvenog časopisa, ne bi trebali biti česti autori radova u njima jer to, između ostaloga, otvara i pitanje objektivnosti recenzentskih postupaka, takva pojava može se tumačiti i drugačije. Naime od navedenih urednika Emil Heršak od svojih devetnaest radova objavljenih u časopisu jedanaest je objavio tijekom obavljanja funkcije glavnog urednika, Milan Mesić tri rada od ukupno šesnaest te Jadranka Čačić-Kumpes jedan od ukupno dvanaest radova. Ti podaci mogu upućivati na stručnost tih autora u temama kojima se bavi MET te se ne moraju tumačiti negativno. U obzir se može uzeti i manjak autora koji bi se bavili određenom tematikom jer časopis djeluje u malenoj hrvatskoj znanstvenoj zajednici, što može biti razlog većoj eksponiranosti određenih autora (Jokić i Zauder, 2013). 
Slika 4. Pet najproduktivnijih autoria prema broju objavljenih radova Figure 4. Five most productive authors by number of published papers

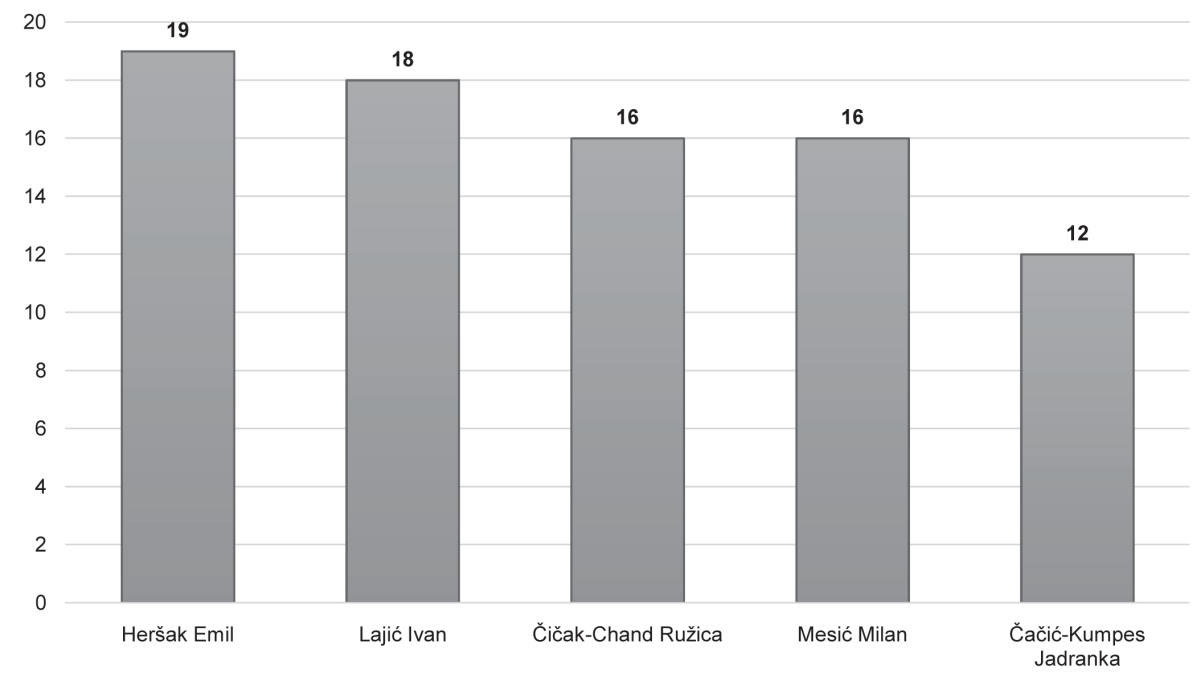

Može se reći kako je produktivnost jedan od uvjeta za citiranost rada određenog autora. Promatrajući citiranost određenog autora, možemo zaključivati o odjeku rezultata njegovih istraživanja u znanstvenoj zajednici u kojoj djeluje. Citiranost nam govori koliko su nečiji radovi prepoznati te ćemo vidjeti kako je zapravo većina najproduktivnijih autora u MET-u među dvadeset najcitiranijih autora (tablica 2). Ukupna citiranost autora iz tablice 2 vidljiva je u tablici 3 po uredničkim razdobljima.

Tablica 2. Dvadeset najcitiranijih autora u časopisu Migracijske i etničke teme 1985. - 2013.

Table 2. Twenty most cited authors in the journal Migration and Ethnic Themes, 1985-2013

\begin{tabular}{lc|lc}
\hline Autor & Broj citata & Autor & Broj citata \\
\hline Nejašmić, I. & 93 & Švob, M. & 32 \\
\hline Heršak, E. & 68 & Antić, Lj. & 31 \\
\hline Mesić, M. & 66 & Čizmić, I. & 30 \\
\hline Lajić, I. & 65 & Klaić, N. & 30 \\
\hline
\end{tabular}




\begin{tabular}{lc|lc}
\hline Autor & Broj citata & Autor & Broj citata \\
\hline Katunarić, V. & 54 & Mežnarić, S. & 27 \\
\hline Smith, A. D. & 44 & Portes, A. & 27 \\
\hline Klinar, P. & 42 & Vresk, M. & 27 \\
\hline $\begin{array}{l}\text { Wertheimer- } \\
\text { Baletić, A. }\end{array}$ & 42 & Kymlicka, W. & 25 \\
\hline $\begin{array}{l}\text { Friganović, M. } \\
\text { Castles, S. }\end{array}$ & 37 & Čičak Chand, R. & 23 \\
\hline
\end{tabular}

Tablica 3. Pet najcitiranijih autora u časopisu Migracijske i etničke teme po uredničkim razdobljima 1985. - 2012.

Table 3. Five most cited authors in the journal Migration and Ethnic Themes by editorial periods, 1985-2012

\begin{tabular}{|c|c|c|c|c|}
\hline $\begin{array}{c}\text { Milan Mesić } \\
\text { (1985. - 1989.) }\end{array}$ & $\begin{array}{c}\text { Emil Heršak } \\
(1990 . \text { - 2001.) }\end{array}$ & $\begin{array}{l}\text { Laura Šakaja } \\
(2002 . \text { - 2004.) }\end{array}$ & $\begin{array}{c}\text { Jadranka } \\
\text { Čačić-Kumpes } \\
(2005 .-2008 .)\end{array}$ & $\begin{array}{c}\text { Sanja Lazanin } \\
(2009 .-2012 .)\end{array}$ \\
\hline Klinar, P. (30) & Heršak, E. (31) & $\begin{array}{c}\text { Cyryla, S. M. } \\
(15)\end{array}$ & Sekulić, D. (14) & $\begin{array}{c}\text { Nejašmić, I. } \\
(45)\end{array}$ \\
\hline Čizmić, I. (20) & $\begin{array}{c}\text { Nejašmić, I. } \\
(30)\end{array}$ & $\begin{array}{c}\text { Katunatić, V. } \\
\text { (13) }\end{array}$ & $\begin{array}{c}\text { Smith, A. D. } \\
\text { (11) }\end{array}$ & Lajić, I. (28) \\
\hline Antić, Lj. (19) & Mesić, M. (28) & Mesić, M. (13) & $\begin{array}{c}\text { Nejašmić, I. } \\
(10)\end{array}$ & $\begin{array}{c}\text { Kymlicka, W. } \\
\text { (15) }\end{array}$ \\
\hline Heršak, E. (15) & $\begin{array}{c}\text { Smith, A. D. } \\
(21)\end{array}$ & Lajić, I. (11) & Heršak, E. (9) & Vresk, M. (15) \\
\hline $\begin{array}{c}\text { Katunarić, V. } \\
\text { (11) }\end{array}$ & Lajić, I. (20) & $\begin{array}{l}\text { Wertheimer } \\
\text { Baletić, A. (9) }\end{array}$ & $\begin{array}{c}\text { Čaldarović, O. } \\
\text { (6) }\end{array}$ & Portes, A. (14) \\
\hline
\end{tabular}

Kako smo već naveli, posebnu pozornost obratit ćemo na razdoblje od 2002. do 2012. te stoga slika 5 pokazuje ukupni broj radova u uredničkim razdobljima. 
Slika 5. Broj objavljenih radova u časopisu Migracijske i etničke teme tijekom triju uredničkih razdoblja 2002. - 2012.

Figure 5. Number of published papers in the journal Migration and Ethnic Themes during the three editorial periods, 2002-2012

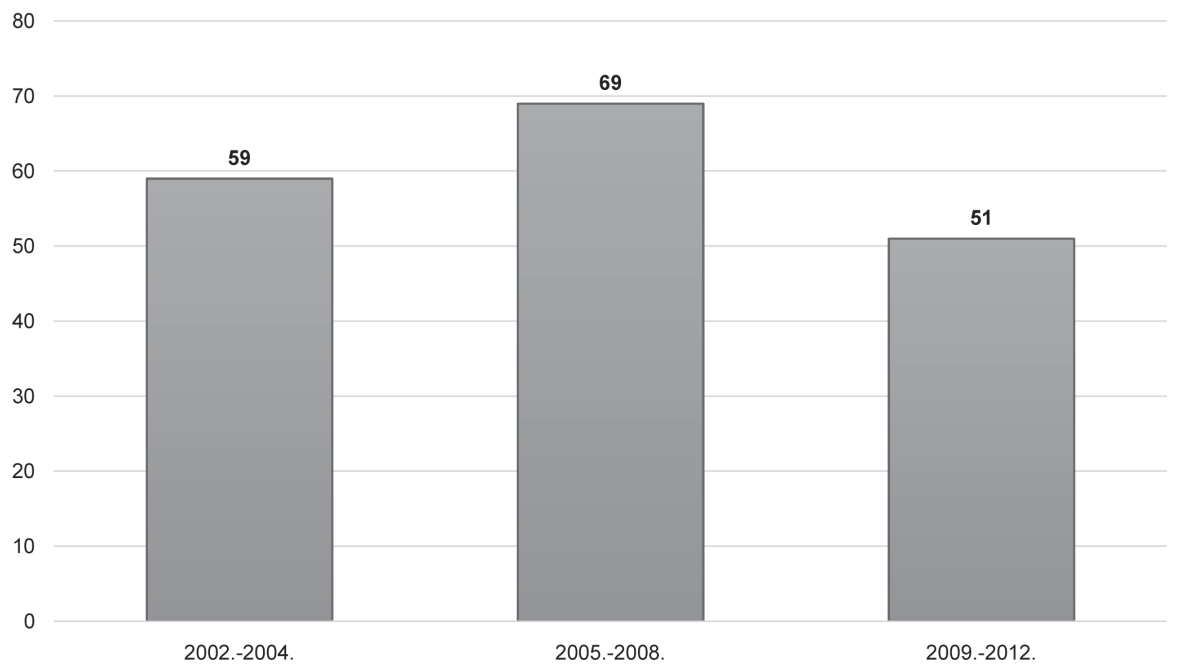

Od 2002. do 2004. objavljeno je 59 radova, a od toga 54 rada potpisuje jedan autor, što je $91,5 \%$, te pet radova potpisuju dva autora $(8,5 \%)$. Od 2005. do 2008. objavljeno je ukupno 69 radova. Od toga 43 ima jednog autora $(62,3 \%), 22$ rada dva autora $(31,9 \%)$ te četiri rada tri autora $(5,8 \%)$. Od 2009. do 2012. objavljen je $51 \mathrm{rad}$, od čega $31 \mathrm{rad}$ ima jednog autora (60,8\%), šesnaest dva autora $(31,4 \%)$, tri rada tri autora $(5,9)$ te jedan rad pet autora $(1,9 \%)$. Na slici 6 jasno se vidi da između prvog i drugog uredničkog razdoblja značajno pada broj jednoautorskih radova. Takav značajni pad jednoautorskih radova nije zabilježen između drugoga i trećega uredničkog razdoblja. Specifičnost suvremenog autorstva u većini znanstvenih disciplina i područja jest postupno i sve veće smanjenje broja jednoautorskih radova. U nekim područjima kao što su kemija i biomedicina gotovo da više i ne postoje jednoautorski radovi. Autorstvo postaje kolektivna aktivnost, s velikim brojem suautora. Pregled literature koja se bavi povijesnim razvojem autorstva može se naći u Cronin (2001). Većina istraživanja dominaciju višeautorstva $u$ odnosu na jednoautorske radove povezuje $s$ interdisciplinarnošću i suradnjom (Youtie i Bozeman, 2014; Zamora Bonilla, 2012).

Evidentna je dominacija jednoautorskih radova, no i njezin je trend negativan, što znači da suautorstvo bilježi pozitivan trend. U posljednjem 
razdoblju objavljen je jedan rad s pet autora, što je, sveukupno gledajući, maksimalan broj autora (slika 6).

Slika 6. Broj autora radova u časopisu Migracijske i etničke teme tijekom triju uredničkih razdoblja, 2002. - 2012.

Figure 6. Number of authors of the papers published in the journal Migration and Ethnic Themes during the three editorial periods, 2002-2012

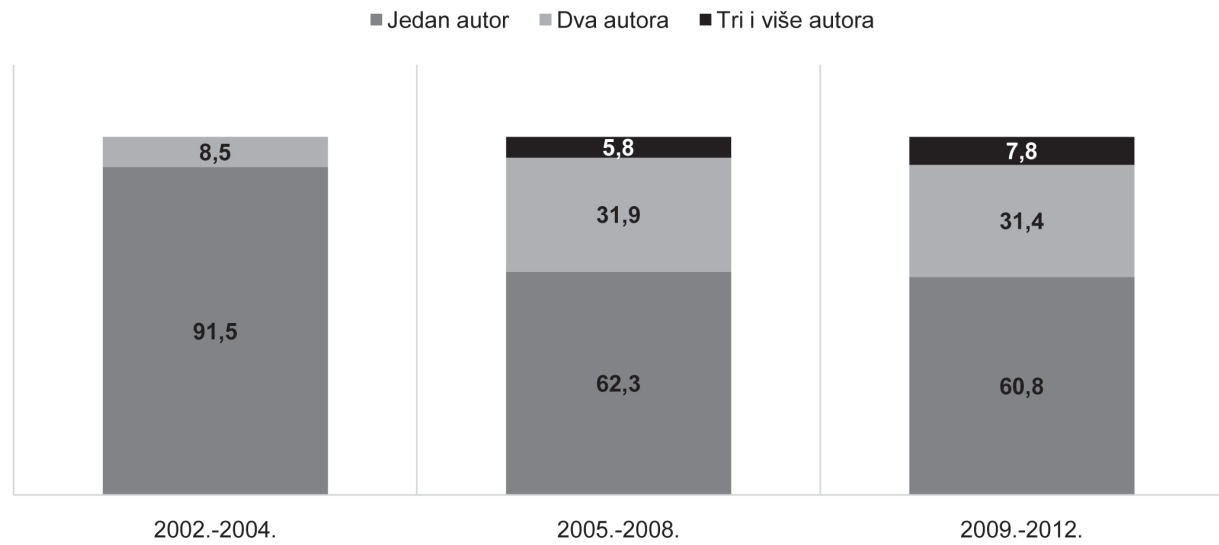

Ukupni je broj autora u gotovo trideset godina postojanja časopisa $\mathrm{Mi}$ gracijske i etničke teme 630, što je prosječno 1,3 autora po radu.

Što se tiče učestalosti pojavljivanja autora iz određenih ustanova, rezultati su očekivani i još jednom potvrđuju nacionalnu orijentaciju časopisa, no prisutna je i suradnja na međunarodnoj i regionalnoj razini. Najveći je broj radova iz Instituta za migracije i narodnosti (izdavač MET-a), 186 jednoautorstva te trinaest radova u suautorstvu s ostalim ustanovama. Po učestalosti objavljenih radova na drugom je mjestu Filozofski fakultet s 28 radova, na trećemu Institut društvenih znanosti »Ivo Pilar« sa sedam radova te na četvrtome Prirodoslovno-matematički fakultet, Odsjek za geografiju, s pet radova.

Među zastupljenijim ustanovama izvan Hrvatske nalaze se Faculty of Languages and Linguistics, Malaya, Kuala Lumpur, sa sedam radova, Institut društvenih nauka, Beograd, sa šest radova, Inštitut za narodnostna vprašanja, Ljubljana, sa šest radova te s četiri rada University of Umeå, Sweden i Fakulteta za sociologijo, politične vede in novinarstvo iz Ljubljane. 
Slika 7. Najzastupljenije ustanove u regiji čiji su zaposlenici objavljivali u časopisu Migracijske $i$ etničke teme

Figure 7. Most represented regional institutions whose employees published in the journal Migration and Ethnic Themes

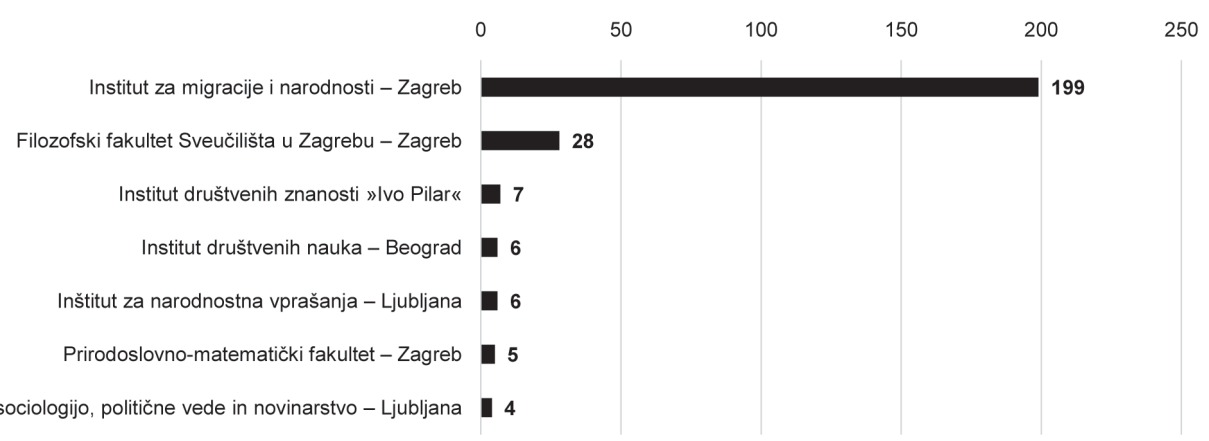

\subsection{Analiza posredne citiranosti MET-a}

Iako MET nije indeksiran u bazama Scopus i WoS, pa nije moguće dobiti njegovu izravnu citiranost, analizirali smo posrednu citiranost preko časopisa indeksiranih u tim bazama kako bismo istražili recepciju objavljenih rezultata istraživanja. Posrednom citiranošću, analizom referenci radova objavljenih u časopisima koje indeksiraju te dvije baze, došli smo do podataka koji su časopisi i s kojom učestalošću citirali radove iz MET-a.

Analizom prikupljenih podataka utvrdili smo da su prema bazi Scopus citirana 232 rada u 116 časopisa. U 88 časopisa rad iz MET-a citiran je jednom, u njih šesnaest dva puta, a u dvanaest tri ili više puta. U časopisu Instituta društvenih znanosti »Ivo Pilar « Društvena istraživanja MET je citiran 31 put, što je najveći broj citata. U dvanaest časopisa koji su se tri ili više puta referirali na MET osam je domaćih, a četiri su strana. Tri časopisa s najvećim brojem citata jesu Društvena istraživanja (31), Hrvatski geografski glasnik (16) i Collegium Antropologicum (7). Pregled časopisa koji su citirali MET, prema bazi podataka Scopus, donosimo u Prilogu 1.

Podaci iz baza Web of Science - WoS manjeg su obujma zbog same naravi baze, koja prikuplja podatke iz manjeg broja časopisa, pa je ukupni broj časopisa u kojima je citiran MET (pod oba naziva) 49, a ukupni broj citata 145. Broj hrvatskih časopisa indeksiranih u bazama WoS koji citiraju MET bio je devet s ukupno 39 citata $(26,9 \%)$. Citiranost u preostalih četrdeset časopisa upućuje na zaključak velike raspršenosti i relativno slabe vidljivosti. Pregled časopisa koji su citirali MET, prema bazama podataka WoS, nalazi se u Prilogu 2. 
Prva institucija po zastupljenosti objavljenih radova u MET-u koja ima svoj časopis, a nije Institut za migracije i narodnosti, jest Institut društvenih znanosti »Ivo Pilar«, pa ne čudi činjenica da su upravo autori iz tog instituta najviše puta citirali, prema podacima obiju baza, radove iz MET-a.

\subsection{Analiza citiranih referenci}

Analiza referenci provedena je na uzorku triju vrsta citiranih publikacija: knjiga, zbornika i časopisa. Navedeni podaci odnose se na razdoblje od prvog broja časopisa 1985. do 2013., u kojem je objavljen 497 rad. Ukupni je broj referenci 12.732, iz čega proizlazi da prosječni rad ima 25,6 referenci. Knjige su u skupu svih referenci upotrijebljene literature. Ima ih 4894, što je 9,8 po radu, a od toga su 1432 domaće $(29,3 \%)$ i 3462 strane (70,7\%). Ukupni je broj zbornika u referencama 2015, tj. 4,1 zbornik po radu. Od toga je domaćih 519 (25,8\%), a stranih 1496 (74,2\%).

Ukupni je broj radova iz časopisa u referencama 3692, odnosno 7,4 radova iz časopisa citiranih po radu. Od toga je broj radova iz domaćih časopisa $1462(39,6 \%)$, a iz stranih $2230(60,4 \%)$ referenci, što je prikazano na slici 8.

Slika 8. Omjer domaćih i stranih časopisa u referencama časopisa Migracijske i etničke teme, 1985. - 2013.

Figure 8. Ratio of domestic and foreign journals in the references of the journal Migration and Ethnic Themes, 1985-2013

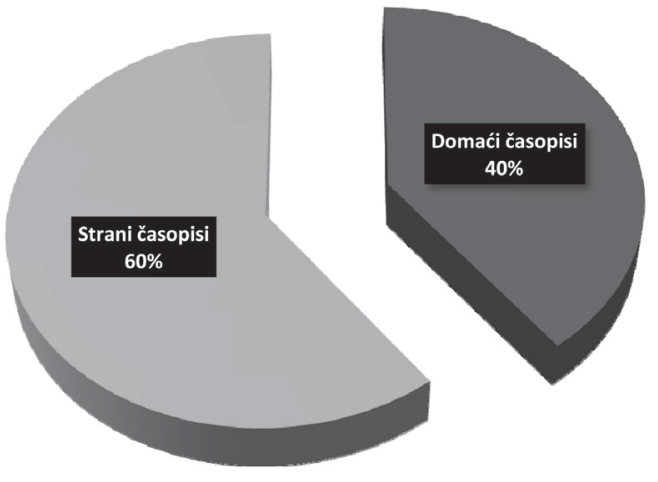

U cjelokupnom razdoblju izlaženja MET-a vidljivo je kako se autori većinom referiraju na radove objavljene u stranim časopisima. No kada se izdvoji dvadeset najcitiranijih časopisa, ipak su domaći zastupljeniji brojem citiranih radova, usprkos tome što su domaći i strani časopisi jednako za- 
stupljeni. Ne čudi da je na prvome mjestu upravo MET zbog toga što autori kroz tu publikaciju razvijaju područje migracija i etničnosti citirajući rezultate istraživanja međusobno. Drugi je najzastupljeniji časopis International Migration Review, što pokazuje autorsku međunarodnu orijentaciju. U dvadeset najcitiranijih časopisa nalazi se osam domaćih sa 656 citiranih radova te dvanaest stranih s 435 citiranih radova (tablica 4). U prilog multidisciplinarnosti MET-a ide i podatak da je 2561 preostali rad $(69,4 \%)$ raspodijeljen po raznim stranim i domaćim časopisima sa po nekoliko citiranih radova.

Tablica 4. Dvadeset najcitiranijih časopisa u Migracijskim i etničkim temama, 1985. - 2013.

Table 4. Twenty most cited journals in the journal Migration and Ethnic Themes, 1985-2013

\begin{tabular}{|c|c|c|c|}
\hline Naziv časopisa & $\begin{array}{l}\text { Broj } \\
\text { referenci }\end{array}$ & Naziv časopisa & $\begin{array}{l}\text { Broj } \\
\text { referenci }\end{array}$ \\
\hline $\begin{array}{c}\text { Migracijske teme/Migracijske } i \\
\text { etničke teme }\end{array}$ & 282 & Naše teme & 28 \\
\hline International Migration Review & 117 & Prosveta & 28 \\
\hline Društvena istraživanja & 103 & Sociologija & 26 \\
\hline Revija za sociologiju & 76 & Razprave in gradivo & 25 \\
\hline $\begin{array}{l}\text { Geografski glasnik/Hrvatski } \\
\text { geografski glasnik }\end{array}$ & 75 & Political Psychology & 23 \\
\hline Ethnic and Racial Studies & 55 & Studi emigrazione & 22 \\
\hline $\begin{array}{c}\text { Sociologija sela/Sociologija } i \\
\text { prostor }\end{array}$ & 49 & $\begin{array}{c}\text { American Sociological } \\
\text { Review }\end{array}$ & 21 \\
\hline $\begin{array}{l}\text { Journal of Ethnic and Migration } \\
\text { Studies }\end{array}$ & 42 & $\begin{array}{c}\text { Časopis za suvremenu } \\
\text { povijest }\end{array}$ & 17 \\
\hline Canadian Ethnic Studies & 34 & Teorija in praksa & 17 \\
\hline International Migration & 34 & $\begin{array}{c}\text { The Journal of Multilingual } \\
\text { and Multicultural } \\
\text { Development }\end{array}$ & 17 \\
\hline
\end{tabular}


Prosječno godište citiranih zbornika, odnosno članaka iz časopisa u referencama u istom razdoblju jest 1985., dok je za knjigu prosjek 1982. godina. Medijan starosti citiranih radova u časopisima jest 1995. godina.

Zanimljivo je usporediti broj radova bez referenci i onih koji ih imaju više od devedeset. Ukupni je broj objavljenih radova bez referenci trinaest, od čega je šest radova izvorni znanstveni rad, četiri su pregledna rada, tri prethodna priopćenja te jedan pregledni rad s jednom referencom. Od šest spomenutih izvornih znanstvenih radova bez referenci čak tri imaju istog autora. Nasuprot izvornim znanstvenim radovima bez ijedne reference, analizom podataka došli smo do izvornoga znanstvenog rada koji se na svojih četrdeset stranica referira na 383 publikacije, od čega je 157 knjiga $(40,9 \%)$. S pravom se možemo zapitati kako je moguće napraviti izvorni znanstveni rad, a da se autor ne referira ni na jednu publikaciju. No s druge je strane opravdano zapitati se je li moguće da je autor u svom istraživanju pročitao 157 knjiga te se uz njih referirao na još 35 radova iz zbornika, 53 rada iz časopisa te 138 ostalih oblika publikacija kao što su doktorski radovi, konferencijski radovi i sl. Kada se takav rad sadržajno analizira, pokaže se kako se autor bavio analizom i komparacijom altajskih jezika te u radu donosi bibliografiju najvažnije literature s područja lingvistike. Dakle veliki broj referenci navedenih u radu kao bibliografija određenog područja te manji broj referenci nekog uskog područja nisu sumjerljivi jer se ne mogu dovesti u ravnopravan odnos. Još nevjerojatnije može zvučati rezultat odnosa stranica i broja radova na koje se autor referira. Tako primjerice jedan autor na devet stranica svoga izvornog znanstvenog rada navodi 126 referenci, što znači da je po jednoj stranici u prosjeku citirao četrnaest izvora. I taj će se slučaj pokazati opravdanim jer je riječ o radu koji se bavi analizom i usporedbom propagandnih letaka i poruka kojima je jedna grupa ljudi htjela utjecati na drugu.

\subsection{Analiza citiranih referenci od 2002. do 2013.}

Od 2002. do 2013. uočava se porast ukupnog broja citiranih bibliografskih jedinica u odnosu na prethodno razdoblje, a odnosi se na veći broj citiranih članaka iz časopisa.

Prosječno godište citirane literature od 2002. do 2004. za knjigu je 1990., za zbornik 1991., a za članke iz časopisa 1993. Od 2005. do 2008. prosječno je godište citiranih knjiga 1989., za zbornik 1994., a za članke iz časopisa 1998. Od 2009. do 2013. prosječno je godište knjige 1994., zbornik 1997., a za članke iz časopisa 1997. Dakle vidljiv je pozitivni trend u pogledu upotrebe sve recentnije literature. 
Slika 9. Trendovi citiranja tijekom triju razdoblja prema vrsti publikacije

Figure 9. Trends in citations during the three periods, by type of publication

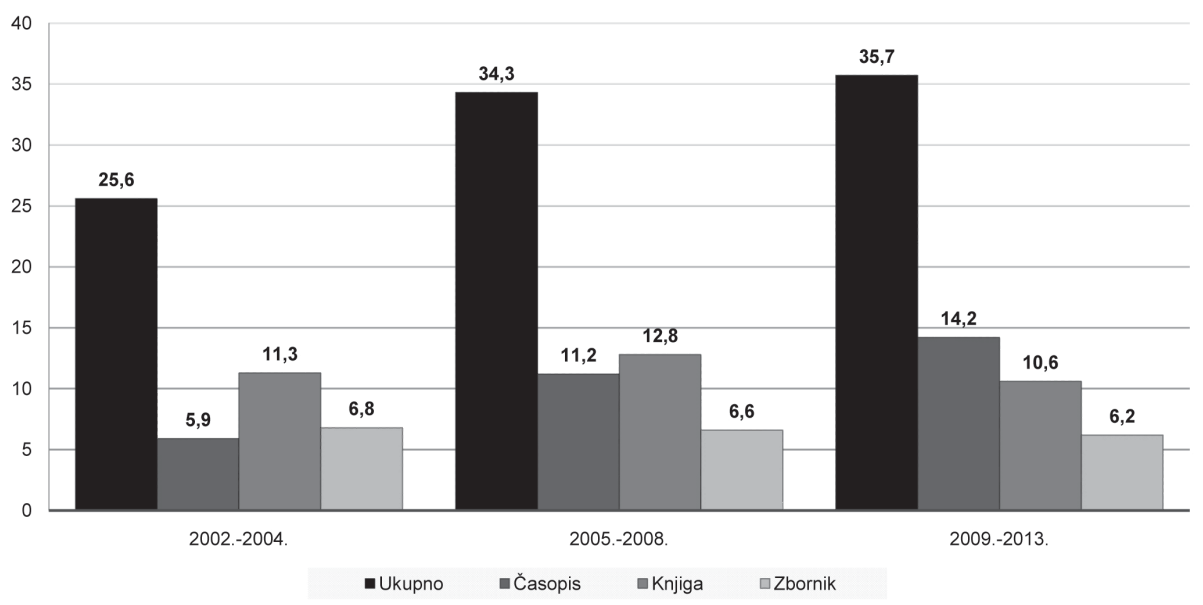

Ovim smo radom htjeli pokazati rezultate bibliometrijske analize, dok za sadržajnu analizu valja pričekati nekoga drugoga, stručnijega, i području istraživanja časopisa bližega autora.

\section{ZAKLJUČAK}

Časopis Migracijske i etničke teme kao multidisciplinaran i interdisciplinaran časopis sadržava radove koji se bave fenomenima migracija, etničnosti i identiteta iz različitih polja društvenih i humanističkih znanosti. Analiza bibliometrijskih pokazatelja pokazala je kako je unatoč objavljenim radovima na stranim jezicima najveći dio radova pisan na hrvatskome. Postotak radova na hrvatskom jeziku iznosi 68,7.

Bibliometrijskom analizom došli smo do rezultata da časopis u svom gotovo tridesetogodišnjem postojanju od prvog broja do danas broji 497 radova, odnosno 288 izvornih znanstvenih radova, 100 preglednih radova, 87 prethodnih priopćenja te četrnaest stručnih i osam konferencijskih radova. Ukupni je broj stranica navedenih radova 7736, odnosno prosječno 15,6 stranica po radu. Analizom citatnih referenci koja je provedena na tri vrste citiranih publikacija (knjiga, zbornika i časopisa) od 1985. do danas dobili smo ukupni broj referenci 12.732, tj. prosječno 25,6 referenci po radu.

Posebnu pozornost usmjerili smo na razdoblje od 2002. do 2013., u kojem se uočava porast ukupnog broja citiranih bibliografskih jedinica u od- 
nosu na prethodno razdoblje, što se odnosi i na veći broj citiranih članaka iz časopisa. Isto razdoblje bilježi pozitivan trend upotrebe recentnije literature. Tome u prilog ide slobodan pristup časopisima na portalima, što znači i njihovu dostupnost široj javnosti. Časopis Migracijske i etničke teme proteklih godina pokazuje pozitivan trend, što se da zaključiti iz rezultata bibliometrijske i citatne analize, ali i povećanje vidljivosti, a to je rezultat dostupnosti široj javnosti putem vlastitih mrežnih stranica (http://imin/met) i Portala znanstvenih časopisa Republike Hrvatske (http://hrcak.srce.hr) na kojemu su dostupna sva godišta časopisa. Da bi se dobila cjelovitija slika o statusu časopisa Migracijske i etničke teme, bilo bi dobro proširiti istraživanje na srodne časopise kao što su Migration: European Journal of International Migration $\mathcal{E}$ Ethnic Relations i Journal of Ethnic and Migration Studies.

\section{LITERATURA}

Azar, O. H. (2014). The Journal of Socio-Economics changes its title to the Journal of Behavioral and Experimental Economics, The Journal of Socio-Economics, 48: 5, doi:10.1016/S10535357(14)00009-2.

Bullis, D. R. i Irving, R. D. (2013). Journals supporting terrorism research: Identification and investigation into their impact on the social sciences, College and Research Libraries, 74 (2): 119-130, doi: 10.5860/crl-314.

Cronin, B. (2001). Hyperauthorship: a postmodern perversion or evidence or a structural shift in scholarly communication practices?, Journal of the American Society for Information Science and Technology, 52 (7): 558-569, doi: 10.1002/asi.1097.

Dukić, Z. (1990). Mjesto sociologije u sistemu znanosti: citatna analiza triju domaćih socioloških časopisa, Revija za sociologiju, 21 (3): 455-465.

Haley, M. R. (2014). Ranking top economics and finance journals using Microsoft academic search versus Google scholar: How does the new publish or perish option compare?, Journal of the Association for Information Science and Technology, 65 (5): 10791084, doi: 10.1002/asi.23080.

Jokić, M. (2001). Časopis Tekstil u pedesetgodišnjem razdoblju od 1952. do 2000. godine - neki od bibliometrijskih pokazatelja, Tekstil, 50 (12): 614-622.

Jokić, M. i Zauder, K. (2013). Bibliometrijska analiza časopisa Sociologija sela/Sociologija i prostor u razdoblju 1963. - 2012., Sociologija i prostor, 51 (2): 331-349, doi: 10.5673/ sip.51.2.11.

Jokić, M., Zauder, K. i Letina, S. (2012). Karakteristike hrvatske nacionalne i međunarodne znanstvene produkcije u društveno-humanističkim znanostima i umjetničkom području za razdoblje 1991-2005. Zagreb: Institut za društvena istraživanja.

Matešić, K. (1984). Unaprijedimo kvalitetu naših časopisa, Primijenjena psihologija, 5: 191-197. 
Nambiar, R. M. K. (2013). Auditing Social Science and Humanities Journals: The View of an Editor in a Malaysian Research University, Journal of Scholarly Publishing, 44 (4): 384-393, doi:10.3138/jsp.44-4-006.

Petak, A., Puljiz, V. i Štambuk, M. (2002). Časopis Sociologija sela, razvoj sela i poljoprivrede, razvoj ruralne sociologije, Sociologija i prostor, 40 (3-4): 157-158.

Pricopie, V. (2013). Social Science Journals in Interwar Romania and the U.S. Model of Sociology, CLCWeb: Comparative Literature and Culture, 15 (4), doi: 10.7771/14814374.2027

Puljiz, V. i Štambuk, M. (1992). Promjene u hrvatskom selu i časopis Sociologija sela, Sociologija i prostor, 30 (3-4): 207-212.

Švenda Radeljak, K. (2006). Časopis Socijalni rad - prvih 10 godina (1960. - 1969.), Ljetopis socijalnog rada, 13 (1): 115-132.

Vojnić, D. (2005). Ekonomski pregled - časopis hrvatskoga društva ekonomista 1935. 2005., Ekonomski pregled, 56 (10): 785-798.

Youtie, J., i Bozeman, B. (2014). Social dynamics of research collaboration: norms, practices, and ethical issues in determining co-authorship rights, Scientometrics, 101 (2): 953-962, doi: 10.1007/s11192-014-1391-7.

Zamora Bonilla, J. (2012). The nature of co-authorship: a note on recognition sharing and scientific argumentation, Synthese, 191 (1): 97-108, doi: 10.1007/s11229-012-0238-0.

\section{PRILOZI}

Prilog 1: Časopisi koji citiraju Migracijske i etničke teme u bazi Scopus (rujan 2014.)

Appendix 1: Journals citing Migration and Ethnic Themes in Scopus citation database (September, 2014)

\begin{tabular}{lr}
\hline Društvena istraživanja & 31 \\
\hline Hrvatski geografski glasnik & 16 \\
\hline Collegium Antropologicum & 7 \\
\hline Dve domovini & 6 \\
\hline Revija za sociologiju & 6 \\
\hline Geografie Sborník ČGS & 5 \\
\hline International Journal of the Sociology of Language & 4 \\
\hline Revija za socijalnu politiku & 4 \\
\hline Sociologija i prostor & 4 \\
\hline Ethnologie française & 3 \\
\hline Ljetopis socijalnog rada & 3 \\
\hline
\end{tabular}




\begin{tabular}{ll}
\hline Suvremena psihologija & 3 \\
\hline Acta Universitatis Carolinae Geographica & 2 \\
\hline Croatica Christiana Periodica & 2 \\
\hline Informatologia & 2 \\
\hline Hrvatska revija za rehabilitacijska istraživanja & 2 \\
\hline Europe Asia Studies & 2 \\
\hline Journal of Ethnic and Migration Studies & 2 \\
\hline Journal of Multilingual and Multicultural Development & 2 \\
\hline Narodna umjetnost & 2 \\
\hline Natura Croatica & 2 \\
\hline Podravina & 2 \\
\hline Population, Space and Place & 2 \\
\hline Psihologijske teme & 2 \\
\hline Socijalna ekologija & 2 \\
\hline Southeastern Europe & 2 \\
\hline Studi Emigrazione & 2 \\
\hline Cultural Geographies & 1 \\
\hline Documents d'Anàlisi Geogràfica & 1 \\
\hline East European Politics and Societies & 1 \\
\hline East European Quarterly & 1 \\
\hline European Integration Online Papers (EIoP) & 1 \\
\hline Ekonomický časopis & 1 \\
\hline Ekonomska istraživanja & 1 \\
\hline Espace Populations Sociétés & 1 \\
\hline Ethnic and Racial Studies & 1 \\
\hline European History Quarterly & 1 \\
\hline European Journal of Criminology & 1 \\
\hline European Journal of Education & 1 \\
\hline European Journal of Social Work & 1 \\
\hline European Psychologist & 1 \\
\hline European Societies & 1 \\
\hline Gaceta Sanitaria & 1 \\
\hline Gender Issues & 1 \\
\hline Gender, Place \& Culture & 1 \\
\hline Geografiska Annaler: Series B, Human Geography & 1 \\
\hline Geojournal & 1 \\
\hline & \\
\hline
\end{tabular}




\begin{tabular}{ll}
\hline Glasnik Slovenskega etnološkega društva & 1 \\
\hline Global Networks & 1 \\
\hline Human Organization & 1 \\
\hline International Journal of Politics Culture and Society & 1 \\
\hline International Journal of Urban and Regional Research & 1 \\
\hline International Labour Review & 1 \\
\hline International Migration & 1 \\
\hline International Migration Review & 1 \\
\hline International Review of Sociology & 1 \\
\hline Journal of China Tourism Research & 1 \\
\hline Journal of Environmental Psychology & 1 \\
\hline Annales: Anali za istrske in mediteranske študije-Series Historia et Sociologia & 1 \\
\hline Journal of Financial Crime & 1 \\
\hline Journal of Language and Social Psychology & 1 \\
\hline Annals of Human Genetics & 1 \\
\hline Journal of Social Issues & 1 \\
\hline Journal of Sociology & 1 \\
\hline Journal of Southeast European and Black Sea & 1 \\
\hline Kartografija i geoinformacije & 1 \\
\hline Language and Communication & 1 \\
\hline Library Trends & 1 \\
\hline Anthropological Journal of European Cultures & 1 \\
\hline Marine Policy & 1 \\
\hline Mobilities & 1 \\
\hline Multilingua & 1 \\
\hline Arhiv za higijenu rada i toksikologiju & 1 \\
\hline Naše more & 1 \\
\hline Nationalities Papers & 1 \\
\hline Nations and Nationalism & 1 \\
\hline Asian Journal of Criminology & 1 \\
\hline Oceanic Linguistics & 1 \\
\hline Osterreichische Zeitschrift Fur Volkskunde & 1 \\
\hline Patient Education and Counseling & 1 \\
\hline Peace and Conflict & 1 \\
\hline Perspectives on European Politics and Society & 1 \\
\hline Australian Journal of Social Issues & 1 \\
\hline
\end{tabular}




\begin{tabular}{lr}
\hline Political Research Quarterly & 1 \\
\hline Bulletin de l'Association de Géographes Français & 1 \\
\hline Prospects & 1 \\
\hline Prostor & 1 \\
\hline Canadian Geographer & 1 \\
\hline Radovi Zavoda za hrvatsku povijest & 1 \\
\hline Canadian Journal of Sociology & 1 \\
\hline China Review: An Interdisciplinary Journal on Greater China & 1 \\
\hline Romani Studies & 1 \\
\hline Scottish Geographical Journal & 1 \\
\hline Social and Cultural Geography & 1 \\
\hline Communication Research & 1 \\
\hline Sociological Review & 1 \\
\hline Sociology Compass & 1 \\
\hline Convergencia & 1 \\
\hline Stanovništvo & 1 \\
\hline Croatian Medical Journal & 1 \\
\hline Cross Cultural Research & 1 \\
\hline Tijdschrift Voor Economische En Sociale Geografie & 1 \\
\hline Trends \& Issues in Crime and Criminal Justice & 1 \\
\hline Zbornik Pravnog fakulteta u Zagrebu & 1 \\
\hline
\end{tabular}


Prilog 2: Časopisi koji citiraju Migracijske i etničke teme u bazama Web of Science (rujan 2014.)

Appendix 2: Journals citing Migration and Ethnic Themes in Web of Science citation databases (September, 2014)

\begin{tabular}{|c|c|}
\hline Društvena istraživanja & 25 \\
\hline Dve domovini/Two Homelands & 9 \\
\hline Sociologija i prostor & 3 \\
\hline Journal of Multilingual and Multicultural Development & 3 \\
\hline Collegium Antropologicum & 3 \\
\hline Revija za socijalnu politiku & 2 \\
\hline International Journal of Urban and Regional Research & 2 \\
\hline Suvremena psihologija & 1 \\
\hline Southeast European and Black Sea Studies & 1 \\
\hline Sociological Review & 1 \\
\hline Scottish Geographical Journal & 1 \\
\hline Romani Studies & 1 \\
\hline Revue d'études comparatives Est-Ouest & 1 \\
\hline Prostor & 1 \\
\hline Population, Space and Place & 1 \\
\hline Political Research Quarterly & 1 \\
\hline Oceanic Linguistics & 1 \\
\hline Mitteilungen der Österreichischen Geographischen Gesellschaft & 1 \\
\hline Marine Policy & 1 \\
\hline Ljetopis socijalnog rada & 1 \\
\hline Library Trends & 1 \\
\hline Language Communication & 1 \\
\hline Journal of Sociology & 1 \\
\hline Journal of Social Issues & 1 \\
\hline Journal of Language and Social Psychology & 1 \\
\hline Journal of Ethnic and Migration Studies & 1 \\
\hline Journal of Environmental Psychology & 1 \\
\hline Journal of American Ethnic History & 1 \\
\hline International Migration & 1 \\
\hline International Labour Review & 1 \\
\hline Human Organization & 1 \\
\hline
\end{tabular}




\begin{tabular}{lr}
\hline Geografie & 1 \\
\hline Gaceta Sanitaria & 1 \\
\hline European Journal of Social Work & 1 \\
\hline European Journal of Criminology & 1 \\
\hline European Integration Online Papers (EIoP) & 1 \\
\hline European History Quarterly & 1 \\
\hline Europe Asia Studies & 1 \\
\hline Ekonomska istraživanja & 1 \\
\hline East European Quarterly & 1 \\
\hline East European Politics and Societies & 1 \\
\hline Cultural Geographies & 1 \\
\hline Cross Cultural Research & 1 \\
\hline Croatian Medical Journal & 1 \\
\hline Critique of Anthropology & 1 \\
\hline Communication Research & 1 \\
\hline China Review: An Interdisciplinary Journal on Greater China & 1 \\
\hline Canadian Journal of Sociology & 1 \\
\hline Australian Journal of Social Issues & 1 \\
\hline Annales: Anali za istrske in mediteranske študije- Series Historia et Sociologia & 1 \\
\hline American Sociological Review & 1 \\
\hline
\end{tabular}




\section{Migration and Ethnic Themes - Bibliometric Analysis of the Journal for the Period 1985-2013}

\section{Davor Jokić, Delfa Bartulović-Barnjak}

\section{SUMMARY}

This paper analyzes the journal Migration and Ethnic Themes during the last three decades of its publishing. The research sample consists of all the published issues of the journal from 1985 to 2013, which gives a total number of 497 papers which were subjected to bibliometric analysis. The analyzed papers were divided into the following categories: original scientific paper, preliminary report, scientific review paper, and conference paper and professional paper. The bibliographic description components that were considered relevant for the bibliometric analysis were the type of the paper, year of publication, volume/number, author, number of authors, institutions, number of pages and language of paper. Special attention was given to the analysis of the references cited in the papers. This citation analysis provided the information on the type of cited publications, the amount of cited publications, authors, year of publication of the cited publication, the name of the journal and whether it was a domestic or foreign publication. The analysis was performed on samples from three types of cited publications: books, collection of papers and journals. In order to gain insight into the reception of the research results published in Migration and Ethnic Themes, a citation analysis through the journals indexed in Web of Science and Scopus citation databases was provided. The results of this study could serve as guidelines for the future development of the journal.

KEY WORDS: Migration and Ethnic Themes, bibliometric analysis, citation analysis, scientific journal, Croatia 